\title{
Facilitation Matters: Instructor Perception of Helpfulness of Facilitation Strategies in Online Courses
}

\author{
Florence Martin, Chuang Wang, and Ayesha Sadaf \\ University of North Carolina, Charlotte
}

\begin{abstract}
Online course facilitation is critical to the success of online courses. Instructors use various facilitation strategies in online courses to engage students. One hundred instructors were surveyed on their perception of helpfulness of twelve different facilitation strategies used in online courses to enhance instructor presence, instructor connection, engagement, and learning. Instructors' timely response to questions and instructors' timely feedback on assignments/projects were rated the highest in three of four constructs (instructor presence, engagement, and learning). For instructor connection, ability to contact the instructor in multiple ways was rated the highest. Interactive visual syllabi of the course were rated the lowest in all four constructs. In the openended comments, group projects and synchronous sessions were rated helpful. Descriptive statistics for each of the construct by gender, delivery method, and course level taught are presented. Significant differences were found between gender but analysis of variance failed to detect differences between primary delivery method or course level taught.
\end{abstract}

Keywords: facilitation strategies, instructor presence, online learning, instructor perception, instructor connection

Martin, F., Wang, C., \& Sadaf, A. (2020). Facilitation matters: Instructor perception of helpfulness of facilitation strategies in online courses. Online Learning, 24(1), 28-49. https://doi.org/10.24059/olj.v24i1.1980

\section{Facilitation Matters: \\ Instructor Perception of Helpfulness of Facilitation Strategies in Online Courses}

According to National Center for Educational Statistics (2017), almost twenty million students are enrolled in online courses, and enrollment is likely to grow. By interviewing awardwinning online instructors, (Martin, Budhrani, Kumar \& Ritzhaupt, 2019) found online instructors' roles to be categorized as facilitator, course designer, course manager, subject matter expert, and mentor. In this study, the online instructor role of being a facilitator is examined (Berge, 1995; Pappas, 2014). Online facilitation is described as to be present, available, to share expertise online and model for the students what it means to participate in an online course (Martin, Budhrani, Kumar \& Ritzhaupt, 2019). Gustafson and Gibbs (2000) state that successful online facilitators need to learn strategies to humanize the online course and identify new ways to engage the learners to construct meaning. Online instructors use multiple strategies to facilitate student learning and critical thinking skills (Richardson et al., 2015; Schindler \& Burkholder, 2014), to 
improve students' sense of community (Rovai, 2007), and to promote students' connectedness and learning (Shea, Li, \& Pickett, 2006). Berge's (1995) study on Instructor Roles Model focused on the functions of instructors, which shifted from a subject expert to a course facilitator, and categorized facilitation into four categories: pedagogical, social, managerial, and technical.

Previous literature discussed various types of facilitation strategies in an online setting, such as instructor's feedback to students' assignments (Badiee \& Kaufman, 2014; Thiele, 2003), responses to students' questions (Sheridan \& Kelly, 2010), announcements (Ko \& Rossen, 2010), questionings (Wang, 2014), and video-based course introduction (Jones, Naugle \& Kolloff, 2008). Few studies have looked at students' perception of facilitation strategies in online environments and outcomes (Martin, Wang \& Sadaf, 2018; Shea, Li, \& Pickett, 2006; Hew, 2015). Martin, Wang and Sadaf (2018) reported that instructor's timely response and feedback were highly valued by students on establishing instructor presence, instructor connectedness, engagement and learning. Hosler and Arend (2012) found that course organization and timely specific feedback improved students' participation. Shea, Li, and Pickett (2006) added that instructors' questioning and feedback have positive impact on students' perception of learning and connectedness.

However, few studies have examined instructor perceptions regarding facilitation strategies in online classes and their impact on students' learning achievements. Cavanaugh and Song (2014) compared instructor and students' perspectives regarding audio feedback and written feedback and found that instructors had mixed feelings about giving feedback using audio, whereas students welcome audio feedback. Borup, West, and Thomas (2015) surveyed both students and instructors on their perceptions of text and video feedback in blended courses and discovered that both students and instructors believed that feedback in a written form is more efficient and organized whereas video feedback facilitated supportive communication. Santilli and Beck (2005) examined graduate faculty perceptions of online learning and found that about half of the instructors considered peer interaction as the most significant feature of online discussion and instructor feedback as the second most important feature. Hsiao (2012) discovered that online teachers use several strategies to facilitate online communication, including providing clear guidelines, rubrics and examples for online discussions; showing instructor presence by monitoring students' discussion; and absorbing other strategies that facilitate online discussion. Although these studies identified faculty perceptions regarding a few facilitation strategies, online faculty need to be knowledgeable in the use of facilitation strategies in order to maintain high academic standards in online courses (Bigatel \& Williams, 2015; Al-Salman, 2011).

While specific online facilitation strategies have been examined by other researchers, faculty perception on the helpfulness on a variety of these facilitation strategies and the factors associated with them have not been studied in online settings. In order to address this limitation, Berge (1995) Instructor Roles Model was used as a comprehensive validated model in online instruction to identify a variety of facilitation strategies based on the most important roles of online instructors as learning facilitators. In this study, we examine (a) which facilitation strategies do instructors perceive to be most and least helpful in establishing instructor presence, instructor connection, engagement, and learning in online courses, and; (b) which factors (gender, delivery method, level taught, discipline) are associated with instructor perception of facilitation strategies in online teaching. 


\section{Theoretical framework for online course facilitation}

Berge (1995) categorizes instructor facilitation strategies into four functions: Managerial, Social, Pedagogical and Technical (Figure 1). These instructor facilitation roles were initially described within the online discussion context, but later Berge (2008) changed the roles to focus on broader online learning environments that are "informal, collaborative, reflective learning, with user-generated content" (p. 412). Berge (2008) suggested that some functions of instructors and facilitation strategies may overlap or can be categorized in more than one group.

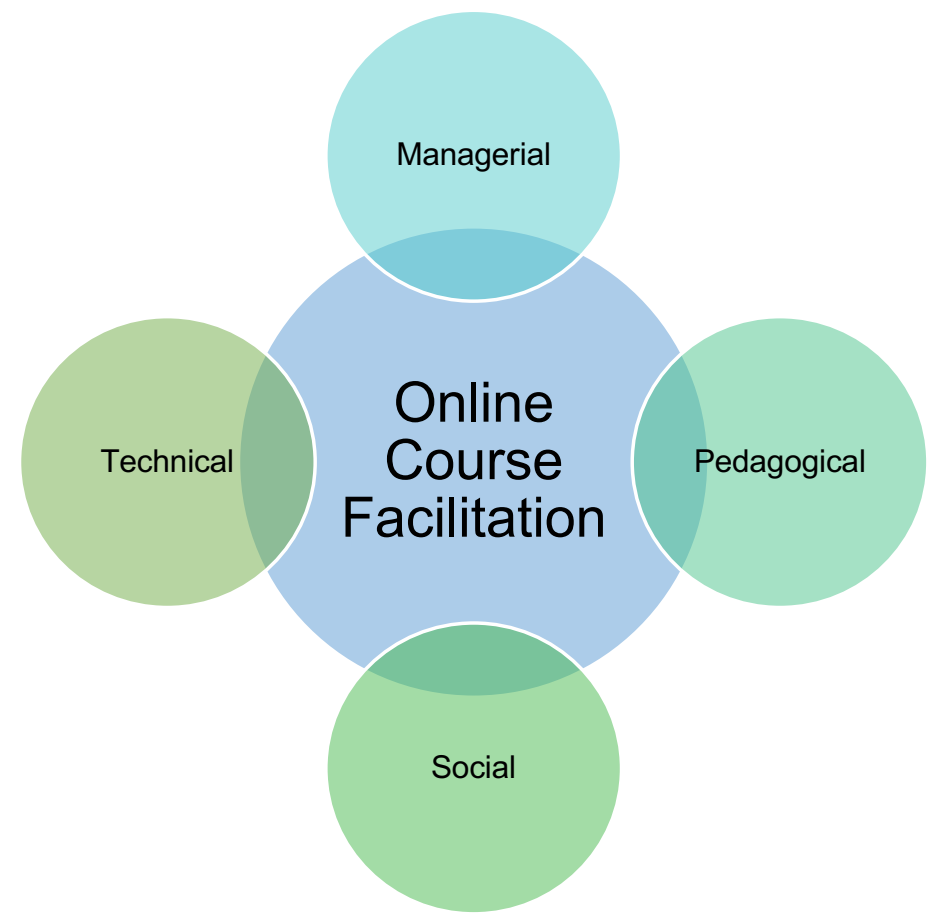

Figure 1. Online Facilitation framework (Berge, 1995).

\section{Pedagogical}

In the pedagogical role, instructors facilitate students' learning and sustain their participation and motivation in an online course (Bawane \& Spector, 2009). Pedagogical facilitation strategies include having clear objectives, encouraging participation, promoting conversations, making the course material relevant, and encouraging contributions (Berge, 1995). Instructors also model effective learning and keep discussions on track, provide special knowledge and perceptions, combine course content, and maintain group harmony (Rohfeld \& Hiemstra, 1995). To facilitate and focus effective discussions, instructors use questions and probes (Berge, 2008). Eskey and Schulte (2010) found that instructors' prompt responses to questions in the discussion and via email are two important facilitation strategies for students to be successful in online courses. Swan (2001) found that student to instructor interaction and active discussions significantly impact student's satisfaction and their perceived learning of the course material in asynchronous online environments.

\section{Managerial}

In the managerial role, instructors design the logistics of the course. Some of the managerial strategies include providing administrative responsibilities, procedural leadership, planning and developing course materials, organizing the course, deciding the dues dates, and 
pacing the online discussions (Anderson, Rourke, Garrison, \& Archer, 2001; Berge, 1995). Wei and Chen (2012) suggested that online instructional design should include a roadmap to effectively guide the learner through the course to foster a positive learning environment. In addition to facilitation and scaffolding, instructors should focus on organizational structure, such as learning objectives, due dates, and expectations to facilitate effective online learning (GonzálezSanmamed, Muñoz-Carril, \& Sangrà, 2014; Richardson et al., 2015). Research indicates that instructors facilitation in terms of prompt response to questions and timely feedback on assignments are important in creating instructor presence, student engagement in their courses, and facilitating higher levels of learning (Hodges \& Cowan, 2012; Martin, Wang \& Sadaf, 2018; Sheridan, \& Kelly, 2010). Ko and Rossen (2010) suggested that regular announcements in an online course can be used to get students attention and remind them about the course activities during the semester. In online courses, instructors sending weekly reminders activities and assignments that are due is helpful for students to manage their time effectively (Kelly, 2014).

\section{Social}

In the social role, instructors encourage and promote meaningful human relationships for working together in a mutual cause. Some of the social facilitation strategies include using introductions to help build the sense of community, facilitating interactivity, modeling the discussions behaviors, and reinforcing online etiquettes (Berge, 1995). In online learning, promoting student-student or student-instructor relationships, developing cohesive groups, and helping students work together for their shared benefit are helpful to the success of online learning activities (Berge, 2008). Ko and Rossen (2010) suggested strategies for instructors to design and facilitate the discussions that include narrowing down topics, starting topic threads, responding to discussion posts, and mentioning student names.

Jones et al. (2008) found that video-based instructor introduction assisted in connecting with the students from the start of the course which contributed to students' growth in the course. Researchers suggest that students demonstrate high levels of cognitive presence in discussions facilitated by well-structured discussions and discussion questions (Oh \& Kim, 2016; Richardson, Sadaf \& Ertmer, 2012; Sadaf \& Olesova, 2017). Lowenthal (2010) recommend instructors to create a space to interact socially with the students, engage them, and provide feedback on time.

\section{Technical}

In the technical role, instructors facilitate a transparent technology environment so that the learners can focus on the academic tasks and learning activities (Berge, 1995). Technical facilitation strategies include providing resources, materials, and other tools to facilitate learning within the online course. Berge (2008) suggested that it is important for the facilitator to help learners become comfortable with the information and communication technologies being used within the online course. Research suggests that using multimedia tools in online courses increase student learning and engagement. Using synchronous tools provide opportunities for instructors and students to interact with each other using various features within the synchronous tools including audio, video, text chat, interactive whiteboard, and applications (Martin \& Parker, 2014). Draus, Curran, \& Trempus (2014) found positive relationships between content created by instructors in the form of videos and student engagement, satisfaction, and retention. Instructorcreated videos assists students grasp the instructional content better and connect with their instructors (Borup et al., 2012; Rose, 2009). Table 1 lists the 12 facilitation strategies proposed by Martin, Wang and Sadaf (2018) categorized by Berge's framework. 
Table 1

Facilitations Strategies in Online Courses (Martin, Wang \& Sadaf, 2018)

\title{
Facilitation Strategies
}

\author{
Social Video-based instructor introduction \\ Instructor being present in the discussion forums \\ Able to contact the instructor in multiple ways \\ Managerial Video-based course orientation \\ Instructors timely response to questions \\ Instructors weekly announcements to the class \\ Pedagogical Instructors timely feedback on assignments/projects \\ Instructor's feedback using various modalities \\ Instructors personal response to student reflections \\ Technical Instructors use of various features in synchronous sessions to interact \\ with students \\ Interactive visual syllabi of the course \\ Instructor created content in the form of short videos/multimedia
}

Helpfulness of online facilitation in this manuscript is examined through four variables, instructor presence, instructor connection, engagement, and learning. The following sections discuss the literature on how facilitation strategy helped the instructor be present in the classroom (instructor presence), how the facilitation strategy helped the instructor get to know the students (instructor connection), how the facilitation strategy helped the instructor engage the students in the online course (engagement), and how the facilitation strategy helped the instructor facilitate learning of the content (learning).

\section{Instructor Presence}

According to Richardson et al. (2015), instructor presence is defined as the "specific actions and behaviors taken by the instructor that project him/herself as a real person" (p. 259). Within the context of online instruction, instructor's role can be seen as more of a facilitator instead of a teacher or lecturer (Richardson \& Swan, 2003). With a focus on the role of facilitator, instructor presence is described as the instructor validating their personal identity by acknowledging and performing their role through various strategies (Martin, Wang \& Sadaf, 2018). Research has demonstrated that instructor' presence influences their students in their affective learning, cognition, and motivation (Baker, 2010), students' satisfaction (Brinkerhoff \& Koroghlanian, 2007), and students' sense of community (Sheridan \& Kelly 2010). Vesely, Bloom, and Sherlock (2007) stated that receiving frequent, timely, and constructive feedback from instructor are important elements of instructor presence for the online students. Richardson, Besser, Koehler, Lim, and Strait (2016) found that instructors perceived their presence as an important factor in online courses. Mandernach, Gonzales, and Garrett (2006) studied instructor interactivity and establishing standards to enhance instructor presence in online discussions. 
Results showed that the majority of instructors believed online instructors' participation in online discussions is important.

\section{Instructor Connectedness}

According to Gallien and Oomen-Early (2008), “Connectedness refers to a person's sense of belonging or presence, feelings of support, and level of communication/interaction with the instructor. Students who perceive a sense of connectedness with their instructor are likely to feel satisfied and perform well in their online courses" (p. 468). Similarly, D'Alba (2014) believes connectedness is the "perceived closeness between the student and instructor as well as the instructor and student" (p. 8). Regarding connectedness and its psychological effects, students with close connection with instructors are likely to build more confidence (Ryan, Gheen \& Midgley, 1998), feel less isolated (Cates \& Slagter van Tryon, 2002), and reduce anxiety (Creasey, Jarvis \& Knapcik, 2009). Creasey et al. (2009) conducted a survey with 94 students to validate the scale of student and instructor relationship and found students were less anxious as they felt more connected with their instructors. Creasey, Jarvis, and Gadke (2009) found that instructor immediacy impacts student achievement orientations which was partially mediated by studentinstructor relationship. Micari and Pazos (2016) reported that instructor connectedness together with self-efficacy and peer alignment are predictors of student satisfaction. LaBarbera (2013) examined how email correspondence between student and instructor influences students' perceived connectedness with instructors. Results showed that students' sense of connectedness were associated with instructor feedback, instructor interaction and support, email correspondence, and their satisfaction with the online course.

\section{Engagement}

Newman, Wehlage and Lamborn (1992) defined student engagement as 'the students' psychological investment in and effort directed toward learning, understanding, or mastering the knowledge, skills, or crafts that academic work is intended to promote" (p. 12). Student engagement denotes student commitment and effort to learning (Krause \& Coates, 2008). Compared to traditional classes, engagement is more important to online courses due to its lack of face-to-face interactions between instructor and students. Engagement has a positive impact on students' satisfaction (Swan 2001), sense of community (Robinson, 2011), and persistence (Kuh et al., 2008). An interactive online course that connects instructors and students can help to eliminate students' feelings of isolation and reduce dropout rates and online attrition (Banna, Lin, Steward, \& Fialkowski, 2015; Boton \& Gregory, 2015). Dixson (2010) studied 186 students enrolled in six universities and found that instructor presence had a positive influence on student engagement. Bolliger and Martin (2018) compared student and instructor perceptions of online student engagement strategies and found that instructors and students showed consensus on the significance of multiple engagement strategies. However, instructors tend to rate most of the strategies higher than students, including "the use of virtual lounges, icebreaker discussion, reflections, peer review, interaction with peers, student moderation of discussions, collaborative activities and projects, and the use of learner's names in discussion forums by instructors" (p. 13).

\section{Learning}

Learning is defined as the attainment of knowledge or skills through experience or education (Martin, Wang \& Sadaf, 2018). In terms of online learning, Ally (2004) defined learning as "the use of the internet to access learning materials, to interact with the content, instructor, and other learners, and to obtain support during the learning process, in order to acquire knowledge, to 
construct personal meaning, and to grow from the learning experience" (p. 7). Online learning benefit learners and instructors in which they can update or access learning materials anytime at any locations. However, there are differences between learner and instructor perceptions of online learning. Tanner, Noser, and Totaro (2009) found that faculty showed less preference to online learning than students when they compared business faculty and undergraduate students' perceptions. Delaney-Klinger, Vanevenhoven, Wagner, and Chenoweth (2014) found that faculty members who lack online teaching experience and the knowledge of using effective tools in online environment are at a disadvantage that may have negative impact on their students' learning.

\section{Role of Instructor Demographics in Online Courses}

Because of the impact online instructors have on students' learning achievements, researchers have explored and found differences in demographics factors that may influence faculty facilitation in online teaching and learning environments (Chang, Lin, \& Song, 2011; Shea, 2007). For example, Chang, et al., (2011) investigated faculty perceptions of teaching efficacy and their relation to their demographic backgrounds and found that education faculty have higher perception of efficacy than faculty in other disciplines, female faculty score higher in class management and learning assessments than male faculty, and faculty with less teaching experience indicate low perception of their teaching efficacy. In another study, Shea (2007) explored instructors' motivations to teach online and found that female faculty were more attracted to online teaching than male faculty, older faculty (those 45 or over) were more motivated to experiment with new pedagogy then were younger faculty, and faculty at four-year institutions were more motivated to teach online than community college faculty. Similarly, Seaman (2009) examined online teaching and course development by gender found that females more confident in instructional skills and are more involved in course development than males. The results of these studies show that since the demographics of online faculty can play an important role in their online teaching, having a clear picture of whether or how demographics affects instructors' perceptions of facilitation strategies is essential to enhance student learning.

\section{Purpose of the Study}

There is limited research focusing on online course facilitation and the studies on facilitation focus on individual facilitation strategies. Since the choices faculty make to facilitate online learning in their courses can have important effects on desired student learning outcomes, identifying their perceptions of facilitation strategies can help enhance student learning in online courses. Therefore, the main purpose of this study is to bring together several strategies and faculty perception of these strategies on how it helps their online teaching. The second purpose is to identify factors associated with faculty perceptions of facilitation strategies. The following questions guided the study:

1. What facilitation strategies do instructors perceive to be most and least helpful in establishing instructor presence, instructor connection, engagement, and learning in online courses?

2. What factors (gender, delivery method, level taught, discipline) are associated with instructor perception of facilitation strategies in online teaching? 


\section{Method}

\section{Data Collection Procedure}

Once the institutional review board approval was received, data was collected using an online survey tool (SurveyShare) that was used at the university where the researchers were affiliated. Email invitations were sent to Association of Educational Communications and Technology (1,900 members) and to the distance education instructors at a southeastern university through the director of distance education (411 instructors). The response rate was at $4.8 \%$. This survey had instructions stating that only faculty who teach hybrid or online courses to complete the survey. The AECT email list has practitioners, students, and faculty. Hence the low response rate was expected. One reminder was sent about two weeks after the initial email. Three \$25 gift cards were given as incentives for their participation in this study through a random drawing.

\section{Participants}

A total of 115 instructors responded to the survey. Out of these 115 respondents, $11 \mathrm{missed}$ at least $10 \%$ of the questions and were therefore dropped from the study. Three respondents reported teaching face-to-face and one person did not report this information, so these four respondents were removed from the analyses. The final sample consisted of 100 instructors who responded to at least $90 \%$ of the questions in the survey. The sample was mostly female instructors $(n=65,65 \%)$ with $34(34 \%)$ male instructors. One person reported "other" as his/her gender identity. Their age ranged from 25 to 68 years with a mean of 49.25 years and a standard deviation of 10.71 years. Half of the participants $(n=48,48 \%)$ taught undergraduate students and the other participants $(n=51,51 \%)$ taught graduate level courses. One participant did not report this information. Most of the participants $(n=83,83 \%)$ reported the delivery method, 72 asynchronous online and 11 synchronous online, and the rest of them reported teaching hybrid courses $(n=17$, $17 \%)$. Faculty were from various disciplines such as arts $(n=20,20 \%)$, business $(n=7,7 \%)$, engineering $(n=6,6 \%)$, health $(n=9,9 \%)$, and education $(n=53,53 \%)$. Five participants $(n=5$, $5 \%)$ did not report this information.

\section{Instrument}

The instrument developed in a previous study on facilitation strategies by Martin, Wang and Sadaf (2018) and administered to students was used in this study. The Cronbach's alpha for students' responses to all items was .98 , and that for students' responses to items used to measure instructor presence, instructor connection, and engagement was $.91, .94$, and .95 , respectively (Martin, Wang \& Sadaf, 2018). The evidence of structural validity was measured by confirmatory factor analysis and the results were satisfactory with all comparative fit index values greater than .93 , normed fit index values greater than .90, and standardized root mean residual values less than .09 (Martin, Wang \& Sadaf, 2018). The online facilitation strategies survey was developed after conducting an extensive literature review on facilitation strategies in online courses and based on the practical experience of expert online instructors. Participants were asked to rate each of the 12 facilitation strategies on a five-point Likert scale from 1 (Strongly Disagree) to 5 (Strongly Agree) for the four aspects of facilitation strategies: instructor presence, instructor connection, engagement, and learning. The questions that the online instructors were asked include:

(1) The following facilitation strategy helped me be present in my classroom (instructor presence);

(2) The following facilitation strategy helped me get to know my students (instructor connection); 
(3) The following facilitation strategy helped me to engage my students in the online course, and;

(4) The following facilitation strategy helped me facilitate learning of the content.

The international consistency, measured by Cronbach's alpha, for instructors' responses to all items was very satisfactory (.96). The Cronbach's alpha for the subscales were .85 for instructor presence, .88 for instructor connection, .87 for engagement, and .81 for learning. In addition to these 12 items, two open-ended questions were used to solicit instructor use of facilitation strategies in addition to those listed in the 12 items: (a) What are some facilitation strategies that you use but not listed here and you have found it helpful? (b) What are some facilitation strategies that you use but not listed here and you have found it least helpful?

\section{Data Analytical Procedure}

Participants' perception of the facilitation strategies were reported with descriptive statistics. Analysis of variance (ANOVA) was used to see if instructor perceptions of facilitation strategies vary across gender, delivery method (hybrid versus online), level taught (undergraduate versus graduate level courses), and discipline (education versus non-education majors). Pearson correlation coefficients were used to represent relations between the perceptions of facilitation strategies and age and the number of online courses taught. Thematic analyses were used to code the instructor responses to open-ended questions.

\section{Results}

\section{Facilitation Strategies}

Instructors rated the helpfulness of facilitation strategies listed on the 12 items with a mean of 3.80 and a standard deviation of 0.63 . Descriptive statistics at the item level and subscale level (instructor presence, instructor connection, engagement, learning) are presented in Table 2.

Participants rated item 4 (Instructor's timely response to questions) most helpful for instructor presence, engagement, and learning. Although the most helpful facilitation strategy for instructor connection was item 3 (Able to contact the instructor in multiple ways), item 4 was rated second to Item 3 only. Item 8 (Instructors timely feedback on assignments/projects) was rated second highest as helpful for instructor presence, engagement and learning. Item 12 (Interactive visual syllabi of the course) was rated least helpful for all four subscales: instructor presence, instructor connection, engagement, and learning. 
Table 2

Instructor Perception of the Helpfulness of Facilitation Strategies

\section{Facilitation Strategies}

Instructor Instructor

Presence Connection Engagement Learning

$M($ SD) $\quad M$ (SD) $\quad M$ (SD) $\quad M$ (SD)

1 Video-based instructor introduction (e.g., Voicethread, animoto, Camtasia )

2 Video-based course orientation (e.g., recording using Camtasia, screencast-o$3.83(1.21)$

$3.40(1.35)$

$3.55(1.25)$
matic)

3 Able to contact the instructor in multiple ways (Contact the Instructor Forum, Email, Phone, Virtual Office hours)

4 Instructors timely response to questions (e.g.,within 24 to 48 hours) via forums, email

5 Instructors weekly announcements to the class (e.g. Every Monday via announcement forum, email)

6 Instructor created content in the form of short videos/multimedia (e.g., Camtasia, articulate modules)

7 Instructor being present in the discussion forums (e.g., refers to students by name, responds to students' posts)

8 Instructors timely feedback on assignments/projects (e.g., within 7 days).

9 Instructor's feedback using various modalities (e.g., text, audio, video, and visuals) on assignments/projects.

1 Instructors personal response to student

0 reflections (e.g., via journals to questions $3.87(1.14)$ $3.05(1.22)$

$4.47(0.78)$

$4.31(0.88)$

$4.29(0.85)$

$3.91(1.01)$

$4.74(0.59)$

$4.18(1.08)$

$4.50(0.74)$

$4.45(0.75)$

$4.17(1.02) \quad 3.25(1.35) \quad 3.92(1.12) \quad 3.78(1.09)$

$3.94(1.09) \quad 3.02(1.29) \quad 3.91(1.04) \quad 4.05(1.06)$

$3.93(1.16) \quad 3.92(1.14) \quad 3.97(1.13) \quad 3.85(1.12)$ on benefits/challenges)

1 Instructors use of various features in

1 synchronous sessions to interact with students (e.g., polls, emoticons, whiteboard, text, or audio and video chat).

1 Interactive visual syllabi of the course

2 (e.g., includes visual of the instructor and other interactive components)
$4.62(0.69)$
4.09 (1.15)
$4.43(0.78)$
$4.43(0.75)$
$3.58(1.26)$
$3.31(1.31)$
$3.61(1.22)$
$4.04(1.10)$
$3.86(1.18)$
$4.06(0.95)$
$4.03(1.05)$
$3.43(1.23)$
$3.45(1.30)$
$3.55(1.28)$

Subscale Total

$3.97(0.65)$

$3.55(0.82)$

$3.86(0.68)$

$3.81(0.64)$ 


\section{Most-Helpful Instructor Facilitation Strategies}

Responses to open-ended questions demonstrate most helpful facilitation strategies (Table 3). Using group projects to support peer learning was rated as helpful by $13 \%$ of the respondents. Another facilitation strategy rated helpful by $11 \%$ of the respondents was using synchronous sessions to explain the content. An exemplary quote is "I have found an always open synchronous chat to be helpful, especially with graduate students. Tools like this could include Skype chat, Slack chat, and the like."

Table 3

\section{Most Helpful Facilitation Strategies}

\section{Codes}

Group projects to support peer learning

Synchronous sessions to present content or answer questions

Feedback to enhance communication between students and instructor.

Students to take active role in leading discussions or presenting projects etc.

Consistent course structure in terms of deadline and content

Having personal interaction with students for clarifying the concepts

\section{Frequency Percentage}

15

13

13

11

9

8

8

7

8

7

7

\section{Least-Helpful Instructor Facilitation Strategies}

The least helpful facilitation strategies are presented in Table 4. Some participants (4\%) did not find synchronous sessions helpful as one of them said that "Synchronous sessions tend to not be well attended and does not really encourage active learning due to limitations in how you can present information." Similarly, discussion boards are not effective for some instructors (4\%): for example, "Required replies to student discussion posts without a specific requirement or prompt. Discussions too hard to read via threads and don't have sufficient new info to make the effort valuable." 
Table 4

Least Helpful Facilitation Strategies

\section{Codes}

Synchronous sessions

Discussion boards

Group projects

Personal interactions

Announcements

Exams and quizzes

\section{Frequency}

\section{4}

4

3

3

2

2

\section{Percentage}

4

4

3

3

2

2

\section{Demographics and Facilitation Strategies}

Since the relationships between the subscales of facilitation strategies and the total score (ranged from .87 to .95) were very high (Table 5), the total score of instructor facilitation strategy instrument was used for the following analyses.

Table 5

Relationships between Subscales of the Facilitation Instrument

\section{Connection}

Presence

Connection

Engagement

Learning

Total

Note. $* * * p<.001$.

\section{Engagement}

$.89 * * *$

$.74 * * *$

\section{Learning}

$.81 * * *$

$.64 * * *$

$.84 * * *$
Total

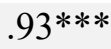

$.87 * * *$

$.95 * * *$

$.89^{* * *}$

Statistically significant differences were noted between male and female instructors who teach online with respect to their perception of the helpfulness of facilitation strategies. Specifically, female instructors endorsed the strategies more than male instructors: $t(97)=2.63$, $p=.01$, Cohen's $\mathrm{d}=0.54$ (medium effect size). Results from four-way ANOVA suggested no statistically significant differences in either delivery method, level taught or discipline after controlling for gender. No statistically significant interaction effects were found either $(p>.05)$. Specifically, no statistically significant differences in instructor perception of facilitation strategies were found between education and non-education faculty: $F(1,90)=0.34, p=.56$, partial $\eta^{2}=$ .004 (small effect size). No statistically significant differences in instructor perception of facilitation strategies were found between faculty who teach online courses and faculty who teach hybrid courses: $F(1,90)=0.96, p=.33$, partial $\eta^{2}=.011$ (small effect size). Moreover, no statistically significant differences in instructor perception of facilitation strategies were found 
between faculty who teach undergraduate courses and faculty who teach graduate courses: $F$ (1, $90)=0.96, p=.33$, partial $\eta^{2}=.011$ (small effect size). Means and standard deviations of instructor perception of facilitation strategies by gender, delivery method, and course level taught are reported in Table 6.

Table 6

Means and Standard Deviations of Instructor Perception of Facilitation Strategies

\begin{tabular}{|c|c|c|c|c|c|c|}
\hline Gender & $\begin{array}{l}\text { Delivery } \\
\text { Method }\end{array}$ & $\begin{array}{l}\text { Level } \\
\text { Taught }\end{array}$ & Discipline & $M$ & $S D$ & $n$ \\
\hline \multirow[t]{8}{*}{ Female } & \multirow[t]{4}{*}{ Hybrid } & \multirow[t]{2}{*}{ Under } & Non-Education & 4.38 & -- & 1 \\
\hline & & & Education & 3.86 & 0.38 & 5 \\
\hline & & \multirow[t]{2}{*}{ Graduate } & Non-Education & 4.29 & -- & 1 \\
\hline & & & Education & 3.64 & 0.63 & 7 \\
\hline & \multirow[t]{4}{*}{ Online } & \multirow[t]{2}{*}{ Under } & Non-Education & 3.83 & 0.69 & 15 \\
\hline & & & Education & 3.81 & 0.33 & 10 \\
\hline & & \multirow[t]{2}{*}{ Graduate } & Non-Education & 3.77 & 0.62 & 7 \\
\hline & & & Education & 4.13 & 0.44 & 19 \\
\hline \multirow[t]{8}{*}{ Male } & \multirow[t]{4}{*}{ Hybrid } & \multirow[t]{2}{*}{ Under } & Non-Education & -- & -- & 0 \\
\hline & & & Education & 3.92 & -- & 1 \\
\hline & & \multirow[t]{2}{*}{ Graduate } & Non-Education & -- & -- & 0 \\
\hline & & & Education & 4.11 & 0.58 & 2 \\
\hline & \multirow[t]{4}{*}{ Online } & \multirow[t]{2}{*}{ Under } & Non-Education & 3.36 & 0.63 & 13 \\
\hline & & & Education & 2.41 & 2.00 & 2 \\
\hline & & \multirow[t]{2}{*}{ Graduate } & Non-Education & 3.68 & 0.50 & 8 \\
\hline & & & Education & 3.88 & 0.63 & 7 \\
\hline
\end{tabular}

\section{Discussion}

In the following section, we discuss the most helpful and least helpful instructor facilitation strategies based on instructors' perception.

\section{Timely response to questions/feedback is very helpful}

Instructors rated timely response to questions and timely feedback on assignments/projects as the two most helpful facilitation strategies in three out of the four constructs (instructor presence, engagement, and learning). This is consistent with findings from research studies that indicate that instructors' facilitation in terms of timely response to questions and timely feedback on assignments are important in establishing instructor presence, student engagement in their courses, and facilitating higher levels of learning (Hodges \& Cowan, 2012; Sheridan \& Kelly, 2010). 
Martin, Wang and Sadaf (2018) noted that instructor's timely response and feedback were highly valued by students. There is consistency in both students and instructors valuing the importance of timeliness in online course facilitation. When instructors respond promptly it establishes immediacy and reduces isolation for the online students. Instructors can use a variety of strategies to provide timely responses, including a group forum where all students can see the questions posted, periodic virtual office hours, and providing collective feedback.

\section{Group Work is helpful}

In the open-ended comments, instructors rated group projects as a helpful facilitation strategy. Research has shown the benefits of group work. Koh, Barbour, and Hill (2010) identified strategies for instructors to improve online group work that include assist group formation, build a sense of connection, be involved in group processes and evaluate group processes. Chang and Kang (2016) recommend instructors to split group work into individual portions, use peer evaluation, create guidelines for communication, and oversee group work processes. Instructors in the open-ended comments listed that group work supports peer learning and these studies confirm the findings.

\section{Synchronous Session helpful or not}

In the quantitative data, the synchronous session was rated as average helpful by the instructors, and the open-ended comments showed $11 \%$ of the instructors consider it as helpful. Synchronous session was considered least helpful by $4 \%$ of the instructors. There has been mixed perception by instructors on the benefits of synchronous session. In online programs that are entirely asynchronous instructors may not see the benefit of facilitation strategies since their students are not mandated to participate in synchronous sessions. Moreover, in this study $72 \%$ of the instructors primarily taught in an asynchronous format. According to Lowenthal, Dunlap, and Snelson (2017), faculty avoid using synchronous communication for various reasons including not having to be in class at specific time, scheduling, and technological challenges. Instructors who see the benefit of synchronous sessions use it to assist student's isolation and provide immediacy in online environment (Martin \& Parker, 2014).

\section{Visual Syllabi is the least helpful}

Using Visual Syllabi was rated the least helpful by the instructors for all four constructs. Although there is reference in the literature about the importance of using a visual syllabi, it is not widely researched (Grigorovici, Nam, \& Russill, 2003; Richards, 2003). Like the instructors, students rated the visual syllabi the least helpful (Martin, Wang \& Sadaf, 2018). They recommended that for visual syllabi to be beneficial, online instructors should create syllabi with hyperlinks and visuals where students can easily find information they need and answers to all their questions.

\section{Demographics}

Female instructors rated the facilitation strategies higher than male instructors. Female faculty were more interested in online teaching compared to male faculty (Shea, 2007) and to be more confident in instructional skills and involved in course development than male faculty (Chang, Lin, \& Song, 2011; Seaman, 2009). The sample in this study included $65 \%$ of female instructors and majority of them teaching online $(83 \%)$. The findings on high ratings of the female instructors is consistent with the previous studies. 


\section{Implications and Recommendations}

This study has implications for online instructors, instructional designers and administrators. The results of this study recommend helpful facilitation strategies for instructors who teach online. It is not only important for the instructors to design an effective online course, but also be an effective facilitator.

\section{Instructors}

Use a variety of facilitation strategies: All the facilitation strategies except the one to use visual syllabi were rated strongly high. This shows that instructors who teach online could use all the 11 strategies in their online teaching and benefit from it. Most important, it is essential for the instructors to provide timely responses to questions and provide timely feedback along with providing multiple ways for the students to contact them.

Set aside time for facilitation: It is important to reserve time for facilitation of the online course. This will assist in responding to questions and in grading work and providing timely feedback to students. Some of the creative strategies to provide timely responses include using a common forum for questions that saves them time from responding to questions individually, using a frequently asked questions that students can read and benefit from, and hosting synchronous office hours to answer student questions. Re-using feedback comments, providing collective feedback to the class, using various modalities to provide feedback (audio, video) in situations where it saves time will assist in providing timely feedback.

Include policies for facilitation in syllabus: Regarding providing timely feedback to students, it is essential to have a policy in the syllabus on the timeframe when students can expect to receive feedback.

\section{Instructional Designers}

This study also has recommendations for instructional designers who support instructors in the design of the online course. Facilitation Strategies are important in addition to design. In many cases, the emphasis is placed on design when instructional designers work with instructors. The findings from this study recommends that instructional designers also recommend faculty to build in various facilitation practices in their online courses. All the recommendations listed above for the online instructors also apply for the instructional designers.

\section{Administrators}

This study has recommendations for administrators who provide support for instructional designers and faculty who teach online.

Teaching evaluation: When peer observation or teaching evaluation forms and processes are created, it is important to include items on facilitation along with design. More and more campuses are adopting processes such as Quality Matters that focus on design only. The findings from this study emphasizes that in addition to design, facilitation is also important. A welldesigned course if not implemented well will not be effective.

Policies on online teaching: Creating policies on presence of online instructors in the online courses will enable instructors to be present in the online course. 


\section{Limitations and Future Research}

This study is limited due to small sample size and low response rate. We received only 100 complete responses, with a response rate of $4.8 \%$, from the instructors surveyed because the AECT email list includes faculty, practitioners, and students. We did not have access to the email list of only faculty. Only faculty who teach online or hybrid were requested to complete the survey. In addition, the data were self-reported so there might be a response bias. For example, instructors who chose to respond to the survey might be different from those who chose not to. In this case, the data would not be representative of the population and conclusions reached in this study would be limited in external validity. Moreover, only the 12 facilitation strategies identified in a previous study (Martin, Wang \& Sadaf, 2018) were used in the survey. They might not be an extensive list of strategies. Future research studies could examine other facilitation strategies and use qualitative methods to interview expert instructors to identity more facilitation strategies in online teaching. 


\section{References}

Ally, M. (2004). Foundations of educational theory for online learning. In Terry, A. \& Elloumi, F. (Ed.), Theory and practice of online learning (pp. 3-32). Athabasca University.

Al-Salman, S. M. (2011). Faculty in online learning programs: Competencies and barriers to success. Journal of Applied Learning and Technology, 1(4), 6-13.

Anderson, T., Rourke, L., Garrison, R., \& Archer, W. (2001). Assessing teaching presence in a computer conferencing context. Journal of Asynchronous Learning Networks, 5(2), 1-17. https://auspace.athabascau.ca/bitstream/handle/2149/725/assessing_teaching_presence.pd f?sequence $=1$

Badiee, F., \& Kaufman, D. (2014). Effectiveness of an online simulation for teacher education. Journal of Technology and Teacher Education, 22(2), 167-186. https://www.learntechlib.org/primary/p/45934/

Baker, C. (2010). The impact of instructor immediacy and presence for online student affective learning, cognition, and motivation. Journal of Educators Online, 7(1), 1-30. doi:10.9743/jeo.2010.1.2

Banna, J., Lin, M. F. G., Stewart, M., \& Fialkowski, M. K. (2015). Interaction matters: Strategies to promote engaged learning in an online introductory nutrition course. Journal of Online Learning and Teaching, 11(2), 249. http://jolt.merlot.org/Vol11no2/Banna_0615.pdf

Bawane, J., \& Spector, J. M. (2009). Prioritization of online instructor roles: Implications for competency-based teacher education programs. Distance Education, 30(3), 383-397. doi: $10.1080 / 01587910903236536$

Berge, Z. L. (1995). Facilitating computer conferencing: Recommendations from the field. Educational technology, 35(1), 22-30. https://www.jstor.org/stable/44428247

Berge, Z. (2008). Changing instructor's roles in virtual worlds. Quarterly Review of Distance Education, 9(4), 407-415. https://www.learntechlib.org/p/106706/

Bigatel, P., \& Williams, V. (2015). Measuring student engagement in an online program. Online Journal of Distance Learning Administration, 18(2). https://www.westga.edu/ distance/ojdla/summer182/bigatel_williams182.html

Bolliger, D. U., \& Martin, F. (2018). Instructor and student perceptions of online student engagement strategies. Distance Education, 39(4), 568-583.

Borup, J., West, R. E., \& Thomas, R. (2015). The impact of text versus video communication on instructor feedback in blended courses. Educational Technology Research and Development, 63(2), 161-184. https://www.learntechlib.org/p/159957/

Boton, E. C., \& Gregory, S. (2015). Minimizing attrition in online degree courses. Journal of Educators Online, 12(1), 62-90. doi:10.9743/jeo.2015.1.6

Brinkerhoff, J., \& Koroghlanian, C. M. (2007). Online students' expectations: Enhancing the fit between online students and course design. Journal of Educational Computing Research, 36(4), 383-393. doi:10.2190/r728-28w1-332k-u115 
Cates, W., \& Slagter van Tryon, P. (2002). Thinking systematically about online learning: Strategies for enhancing social connectedness. Paper presented at the annual meeting of the Association for Educational Communications and Technology, Dallas, TX.

Cavanaugh, A. J., \& Song, L. (2014). Audio feedback versus written feedback: Instructors' and students' perspectives. Journal of Online Learning and Teaching, 10(1), 122. http://jolt.merlot.org/vol10no1/cavanaugh_0314.pdf

Chang, B., \& Kang, H. (2016). Challenges facing group work online. Distance Education, 37(1), 73-88. doi:10.1080/01587919.2016.1154781

Chang, T. S., Lin, H. H., \& Song, M. M. (2011). University faculty members' perceptions of their teaching efficacy. Innovations in Education and Teaching International, 48(1), 4960. doi:10.1080/14703297.2010.543770

Creasey, G., Jarvis, P., \& Gadke, D. (2009). Student attachment stances, instructor immediacy, and student-instructor relationships as predictors of achievement expectancies in college students. Journal of College Student Development, 50(4), 353-372. doi: $10.1353 /$ csd.0.0082

Creasey, G., Jarvis, P., \& Knapcik, E. (2009). A measure to assess student-instructor relationships. International journal for the scholarship of teaching and learning, 3(2), n2. doi:10.20429/ijsot1.2009.030214

D'Alba, O. A. (2014). A case study of student instructor connectedness in an asynchronous modular online environment (Doctoral dissertation). Retrieved from https://scholarworks.gsu.edu/msit_diss/140/

Delaney-Klinger, K., Vanevenhoven, J., Wagner, R., \& Chenoweth, J. (2014). Faculty transitions in online delivery: Make or buy? Tips for developing a 'new to you' online course. Journal of College Teaching \& Learning, 11(1), 45-52. doi:10.19030/tlc.v11i1.8396

Dixson, M. D. (2010). Creating effective student engagement in online courses: What do students find engaging? Journal of the Scholarship of Teaching and Learning, 10(2), 113. https://scholarworks.iu.edu/journals/index.php/josotl/article/view/1744

Draus, P. J., Curran, M. J., \& Trempus, M. S. (2014). The influence of instructor-generated video content on student satisfaction with and engagement in asynchronous online classes. Journal of Online Learning and Teaching, 10(2), 240. http://jolt.merlot.org/vol10no2/draus 0614.pdf

Eskey, M. T., \& Schulte, M. (2010). What online college students say about online instructors and what do online faculty members say about online instruction: A comparison of attitudes. Journal of Online Education, 1-20. http://www.nyu.edu/classes/keefer/waoe/eskeym.pdf

Gallien, T., \& Oomen-Early, J. (2008). Personalized versus collective instructor feedback in the online courseroom: Does type of feedback affect student satisfaction, academic performance and perceived connectedness with the instructor? Internal Journal on ELearning, 7(3), 463-476. https://www.learntechlib.org/primary/p/23582/

González-Sanmamed, M., Muñoz-Carril, P., \& Sangrà, A. (2014). Level of proficiency and professional development needs in peripheral online teaching roles. International Review 
of Research in Open \& Distance Learning, 15(6), 162-187. doi:10.19173/irrodl.v15i6.1771

Grigorovici, D., Nam, S., \& Russill, C. (2003). The effects of online syllabus interactivity on students' perception of the course and instructor. The Internet and Higher Education, 6(1), 41-52. doi:10.1016/S1096-7516(02)00163-X

Gustafson, P., \& Gibbs, D. (2000). Guiding or hiding? The role of the facilitator in online teaching and learning. Teaching Education, 11(2), 195-210.

Hew, K. F. (2015). Student perceptions of peer versus instructor facilitation of asynchronous online discussions: further findings from three cases. Instructional Science, 43(1), 19-38. doi:10.1007/s11251-014-9329-2

Hodges, C. B., \& Forrest Cowan, S. (2012). Preservice teachers' views of instructor presence in online courses. Journal of Digital Learning in Teacher Education, 28(4), 139-145. doi:10.1080/21532974.2012.10784694

Hosler, K. A., \& Arend, B. D. (2012). The importance of course design, feedback, and facilitation: student perceptions of the relationship between teaching presence and cognitive presence. Educational Media International, 49(3), 217-229. doi:10.1080/09523987.2012.738014

Hsiao, E. L. (2012). Synchronous and asynchronous communication in an online environment: Faculty experiences and perceptions. Quarterly Review of Distance Education, 13(1), 15. https://www.learntechlib.org/p/131977/

Jones, P., Naugle, K., \& Kolloff, M. (2008). Teacher presence: Using introductory videos in hybrid and online courses. Learning Solutions. Retrieved March 26, 2018, from www.learningsolutionsmag.com

Kelly, R. (2014). Five things online students want from faculty. Faculty focus. Retrieved November 20, 2019 from https://www.saddleback.edu/uploads/goe/five_things_online_students_want_from_facult y - faculty focus.pdf

Ko, S., \& Rossen, S. (2010). Teaching online: A practical guide. Routledge.

Koh, M. H., Barbour, M., \& Hill, J. R. (2010). Strategies for instructors on how to improve online groupwork. Journal of Educational Computing Research, 43(2), 183-205. doi:10.2190/EC.43.2.c

Kuh, G. D., Cruce, T. M., Shoup, R., Kinzie, J., \& Gonyea, R. M. (2008). Unmasking the effects of student engagement on first-year college grades and persistence. Journal of Higher Education, 79(5), 540-563. doi:10.1353/jhe.0.0019

LaBarbera, R. (2013). The relationship between students' perceptive sense of connectedness to the instructor and satisfaction in online courses. Quarterly Review of Distance Education, 14(4), 209. https://www.infoagepub.com/qrde-issue.html?i=p54c3c328b31d0

Lowenthal, P. R. (2010). Social presence. In Social computing: Concepts, methodologies, tools, and applications (pp. 129-136). IGI Global. doi:10.4018/9781605669847.ch011 
Lowenthal, P., Dunlap, J., \& Snelson, C. (2017). Live Synchronous Web Meetings in Asynchronous Online Courses: Reconceptualizing Virtual Office Hours. Online Learning Journal, 21(4). doi:10.24059/olj.v21i4.1285

Mandernach, B. J., Gonzales, R. M., \& Garrett, A. L. (2006). An examination of online instructor presence via threaded discussion participation. Journal of Online Learning and Teaching, 2(4), 248-260. http://jolt.merlot.org/vol2no4/mandernach.htm

Martin, F., Budhrani, K., Kumar, S., \& Ritzhaupt, A. (2019). Award-winning faculty online teaching practices: Roles and competencies. Online Learning, 23(1), 184-205.

Martin, F., \& Parker, M. A. (2014). Use of synchronous virtual classrooms: Why, who, and how. MERLOT Journal of Online Learning and Teaching, 10(2), 192-210.

Martin, F., Wang, C., \& Sadaf, A. (2018). Student perception of helpfulness of facilitation strategies that enhance instructor presence, connectedness, engagement and learning in online courses. The Internet and Higher Education, 37, 52-65. doi:10.1016/j.iheduc.2018.01.003

Micari, M., \& Pazos, P. (2016). Fitting in and feeling good: the relationships among peer alignment, instructor connectedness, and self-efficacy in undergraduate satisfaction with engineering. European Journal of Engineering Education, 41(4), 380-392. doi:10.1080/03043797.2015.1079814

National Center for Educational Statistics. (2017). Digest of Education Statistics. https://nces.ed.gov/programs/digest/d17/tables/dt17 311.33.asp?current=yes

Newman, F. M., Wehlage, G. G., \& Lamborn, S. D. (1992). The significance and sources of student engagement. In F. M. Newman (Eds.), Student engagement and achievement in American secondary schools. (pp. 11-39) Teachers College, Columbia University.

Pappas, C. (2014). From instructor to effective online facilitator. eLearning Industry. Retrieved January 16, 2020, from https://elearningindustry.com/from-instructor-to-effective-onlinefacilitator

Richards, S. L. (2003). The interactive syllabus: A resource-based, constructivist approach to learning. The Technology Source.

Richardson, J., \& Swan, K. (2003). Examining social presence in online courses in relation to students' perceived learning and satisfaction. Journal of Asynchronous Learning Networks. 7(1). 68-88. http://hdl.handle.net/2142/18713

Richardson, J. C., A. Sadaf, and P. A. Ertmer. (2012). Relationship between types of question prompts and critical thinking in online discussions. In Educational communities of inquiry: Theoretical framework, research and practice, ed. Z. Akyol and D. R. Garrison, 197-222. Hershey, PA: IGI Global. doi:10.4018/978-1-4666-2110-7.ch011

Richardson, J. C., Koehler, A. A., Besser, E. D., Caskurlu, S., Lim, J., \& Mueller, C. M. (2015). Conceptualizing and investigating instructor presence in online learning environments. The International Review of Research in Open and Distributed Learning, 16(3). doi:10.19173/irrodl.v16i3.2123 
Richardson, J. C., Besser, E., Koehler, A., Lim, J., \& Strait, M. (2016). Instructors' perceptions of instructor presence in online learning environments. The International Review of Research in Open and Distributed Learning, 17(4). doi:10.19173/irrodl.v17i4.2330

Robinson, J. (2011). Assessing the value of using an online discussion board for engaging students. Journal of Hospitality, Leisure, Sports and Tourism Education (Pre-2012), 10(1), 13. doi:10.3794/johlste.101.257

Rohfeld, R. W., \& Hiemstra, R. (1995). Moderating discussions in the electronic classroom. Computer Mediated Communication and the Online Classroom, 3, 91-104. http://roghiemstra.com/moderating.html

Rose, K. K. (2009). Student perceptions of the use of instructor-made videos in online and faceto-face classes. MERLOT Journal of Online Learning and Teaching, 5(3). http://jolt.merlot.org/vol5no3/rose_0909.htm

Rovai, A. P. (2007). Facilitating online discussions effectively. The Internet and Higher Education, 10(1), 77-88. doi:10.1016/j.iheduc.2006.10.001

Ryan, A. M., Gheen, M. H., \& Midgley, C. (1998). Why do some students avoid asking for help? An examination of the interplay among students' academic efficacy, teachers' socialemotional role, and the classroom goal structure. Journal of Educational Psychology, 90(3), 528. doi:10.1037//0022-0663.90.3.528

Sadaf, A., \& Olesova, L. (2017). Enhancing cognitive presence in online case discussions with questions based on the practical inquiry model. American Journal of Distance Education, 31(1), 56-12. doi:10.1080/08923647.2017.1267525

Santilli, S., \& Beck, V. (2005). Graduate faculty perceptions of online teaching. Quarterly Review of Distance Education, 6(2). https:/www.infoagepub.com/qrdeissue.html? $\mathrm{i}=\mathrm{p} 54 \mathrm{c} 3 \mathrm{cb} 86 \mathrm{a} 9 \mathrm{a} 11$

Seaman, J. (2009). Online Learning as a Strategic Asset. Volume II: The Paradox of Faculty Voices-Views and Experiences with Online Learning. Results of a National Faculty Survey, Part of the Online Education Benchmarking Study Conducted by the APLU-Sloan National Commission on Online Learning. Association of Public and Land-Grant Universities. https://files.eric.ed.gov/fulltext/ED517311.pdf

Shea, P. (2007). Bridges and barriers to teaching online college courses: A study of experienced online faculty in thirty-six colleges. Journal of Asynchronous Learning Networks, 11(2), 73-128. https://onlinelearningconsortium.org/jaln full issue/volume-11-issue-2-july$\underline{2007 /}$

Shea, P., Li, C. S., \& Pickett, A. (2006). A study of teaching presence and student sense of learning community in fully online and web-enhanced college courses. The Internet and Higher Education, 9(3), 175-190. doi:10.1016/j.iheduc.2006.06.005

Sheridan, K., \& Kelly, M. A. (2010). The indicators of instructor presence that are important to students in online courses. MERLOT Journal of Online Learning and Teaching, 6(4), 767-779. http://jolt.merlot.org/Vol6 No4.htm 
Schindler, L., \& Burkholder Jr, G. J. (2014). Instructional design and facilitation approaches that promote critical thinking in asynchronous online discussions: A review of the literature. Higher Learning Research Communications, 4(4), 10-29. doi:10.18870/hlrc.v4i4.222

Swan, K. (2001). Virtual interaction: Design factors affecting student satisfaction and perceived learning in asynchronous online courses. Distance Education, 22(2), 306-331. doi:10.1080/0158791010220208

Tanner, J. R., Noser, T. C., \& Totaro, M. W. (2009). Business faculty and undergraduate students' perceptions of online learning: A comparative study. Journal of Information Systems Education, 20(1), 29. https://www.learntechlib.org/p/105718/

Thiele, J. E. (2003). Learning patterns of online students. Journal of Nursing Education, 42(8), 3. doi:10.3928/0148-4834-20030801-08

Vesely, P., Bloom, L., \& Sherlock, J. (2007). Key elements of building online community: Comparing faculty and student perceptions. MERLOT Journal of Online Learning and Teaching, 3(3), 234-246. http://jolt.merlot.org/vol3no3/vesely.htm

Wang, Y. M. (2014). Questioning as facilitating strategies in online discussion. Journal of Educational Technology Systems, 42(4), 405-416. doi:10.2190/ET.42.4.f

Wei, C. W., \& Chen, N. S. (2012). A model for social presence in online classrooms. Educational Technology Research and Development, 60(3), 529-545. doi:10.1007/s11423-012-9234-9 